\title{
Behavioral Analysis of Law: An Operant Interpretation of Legal Systems
}

\section{Análise Comportamental do Direito: Uma Interpretação Operante de Sistemas Jurídicos}

\section{Análisis Conductual del Derecho: Una Interpretación Operante de Sistemas Jurídicos}

\author{
Jorge M. Oliveira-Castro', Julio Cesar de Aguiar²
}

\begin{abstract}
[1] Universidade de Brasília e Tribunal de Contas da União [2] Escola de Políticas Públicas e Governo da Fundação Getúlio Vargas I Título abreviado: Behavioral analysis of law I Endereço para correspondência: Instituto de Psicologia, ICC-Sul, Campus Darcy Ribeiro, Universidade de Brasília, Brasília, DF, Brasil, $70910-900$ | Email: Jorge M. Oliveira-Castro - jocastro@unb.br | doi: 10.18761/PAC.2020.v11.n1.08
\end{abstract}

\begin{abstract}
Law is interpreted as a functionally specialized social system, selected by its consequences, whose main function is to control politically defined socially undesirable behavior. Such control derives from legal norms, which are interlocked behavioral patterns, controlled by changes in the probability of application of sanctions, that establish social contingencies of reinforcement to the behavior of group members. These behavioral patterns form a legal behavioral network, in each node of which one response emitted by one person produces discriminative stimuli to the response of a second person, which, in turn, reinforces the occurrence of the first response and generates discriminative stimuli for the behavior of other individuals that take part in subsequent nodes. A great part of behavioral patterns that form legal norms consist of rule uttering responses, occurring in problem-solving contexts, which are verbal responses reinforced by changes in the repertoire of other individuals related to the probability of application of sanctions. Legal rules are composed of three elements: relevant factual assumptions, social goal and legal contingency. This behavior-analytic interpretation of legal systems, which proposes a novel naturalistic legal theory, encourages new areas of empirical research and applications.
\end{abstract}

Keywords: behavior analysis; law; operant behavior; behavioral analysis of law; social systems. 
Resumo: O direito é interpretado como um sistema social funcionalmente especializado, selecionado por suas consequências, cuja função principal é controlar comportamento politicamente definido como socialmente indesejável. Tal controle deriva de normas legais, que são padrões comportamentais entrelaçados, controlados por mudanças na probabilidade de aplicação de sanções, que estabelecem contingências sociais de reforço para o comportamento dos membros do grupo. Esses padrões comportamentais formam uma rede comportamental jurídica, em cada nó da qual uma resposta emitida por uma pessoa produz estímulos discriminativos para a resposta de uma segunda pessoa, o que, por sua vez, reforça a ocorrência da primeira resposta e gera estímulos discriminativos para o comportamento de outros indivíduos que participam de nós subsequentes. Uma grande parte dos padrões comportamentais que formam as normas legais consistem em respostas de enunciação de regras, ocorrendo em contextos de resolução de problemas, que são respostas verbais reforçadas por mudanças no repertório de outros indivíduos relacionadas à probabilidade de aplicação de sanções. As regras legais são compostas por três elementos: pressupostos factuais relevantes, objetivo social e contingência legal. Essa interpretação analítico- comportamental dos sistemas jurídicos, que propõe uma nova teoria jurídica naturalista, encoraja novas áreas de pesquisa empírica e aplicações.

Palavras-chave: análise do comportamento; direito; comportamento operante; análise comportamental do direito; sistemas sociais.

Resumen: El derecho se interpreta como un sistema social funcionalmente especializado, seleccionado por sus consecuencias, cuya función principal es controlar la conducta políticamente definida como socialmente indeseable. Dicho control deriva de las normas legales, que son patrones de conducta entrelazados, controlados por cambios en la probabilidad de aplicación de sanciones, que establecen contingencias sociales de refuerzo a la conducta de los miembros del grupo. Estos patrones de conducta forman una red de conductas jurídicas, en cada nodo de los cuales una respuesta emitida por una persona produce estímulos discriminativos a la respuesta de una segunda persona, lo que, a su vez, refuerza la aparición de la primera respuesta y produce estímulos discriminativos para la conducta de otros individuos que participan en nodos posteriores. Una gran parte de los patrones de conducta que forman las normas jurídicas consisten en respuestas de pronunciación de reglas, que ocurren en contextos de resolución de problemas, las cuáles son respuestas verbales reforzadas por cambios en el repertorio de otras personas relacionadas con la probabilidad de aplicación de sanciones. Las reglas jurídicas se componen de tres elementos: supuestos fácticos relevantes, objetivo social y contingencia jurídica. Esta interpretación analítica del conductual de los sistemas jurídicos, que propone una nueva teoría jurídica naturalista, fomenta nuevas áreas de investigación empírica y aplicaciones.

Palabras clave: análisis de la conducta; derecho; comportamiento operante; análisis conductual del derecho; sistemas sociales. 
In modern societies, a large portion of human behavior is influenced by controlling practices that have been codified by law (cf. Skinner, 1953). Most public policies, for example, are implemented with the aid of laws that prohibit some kinds of conducts and authorize others, which implies that success in the implementation of policies in a given society depends, to a large extent, on the level of control that the legal system exerts over the behavior of its members. From this perspective, in order to increase the effectiveness of public policies, it becomes crucial to improve our knowledge concerning the characteristics of law, the factors that make people obey (or disobey) the law, the variables that influence the behavior of those responsible for applying the law (e.g., police, attorneys, judges), the influence that the text of law has upon people's behavior, to cite just a few important issues.

Several of these questions have been addressed by different areas of enquiry, some more purely theoretical, such as jurisprudence or legal theory (e.g., Albert \& Maluschke, 2013; Hart, 1994; Kelsen, 1960/1998; Posner, 1990; Schauer, 2015; Teubner, 1993), and some predominantly empirical, such as criminology (e.g., Nagin, 1998, 2013a, 2013b), economic analysis of law (Posner, 2007), experimental criminology (e.g., Ready \& Young, 2015) and experimental economics (e.g., Abbink, Dasgupta, Gangadharan \& Jain, 2014). Although such diverse lines of research have advanced our knowledge concerning the effects of some of the variables that influence behavior, in our view, the field lacks a general theoretical framework that might help integrate findings and concepts stemming from various empirical traditions to those developed by legal theorists. One of the main obstacle for such integration is the difference, frequently discussed, between the world of facts and the world of norms (Habermas, 1996). Exploring, briefly, some of the major themes of investigation in legal theory may help clarify this point, which we do next.

Research in legal theory has been particularly involved with the identification of the essential characteristics of law. The opening sentence of Hart's much cited book, The Concept of Law, stresses the complexity of the issue and the diversity of ideas in legal theory: "few questions concerning human society have been asked with such persistence and answered by serious thinkers in so many diverse, strange, and even paradoxical ways as the question 'What is law"' (Hart, 1994, p. 1). For instance, there has been much discussion in jurisprudence concerning whether coercion and the possibility of using physical force are essential characteristics of law or whether people follow the law (independently of its coercive consequences) simply because it is the law (cf. Schauer, 2015). Other common debated themes have revolved around whether law is ultimately based upon existing moral assumption that would be universal and discovered through reason, or whether law is a hierarchical system of rules the application of which does not necessarily involve moral discussions, or whether a science of law is possible and what type of science it would be (e.g, Albert \& Maluschke, 2013; Hart, 1994; Kelsen, 1960/1998; Schauer, 2015; Teubner, 1993). One main issue that has permeated many debates in legal theories involves the relations between what in fact happens in a given society, concerning for example how people behave and how their behavior is (or not) punished (frequently called social norms), and what is prescribed to happen by law, that is, how people should behave according to what is specified by law (frequently called legal rules, cf. Kelsen, 1960/1998). In jurisprudence, this distinction is frequently referred to as the difference between law in action and law in the books, and interpreted as reflecting an irreconcilable difference between what is and what should be, which produces an insuperable gap between the world of facts and the world of morals (cf. Kelsen, 1960/1998, Albert \& Maluschke, 2013).

One of the main purposes of the present paper is to introduce an interpretative framework that integrates these two "worlds" of facts and norms in a theoretically consistent approach, which is compatible with most empirical work conducted on the theme. As it will be explained later, such integration becomes possible because legal norms are interpreted as behavioral patterns of members of a given group that control the behavior of individuals on the basis of reinforcement and punishment, establishing programmed social contingencies of reinforcement, according to which, within the group, certain types of behaviors are consistently followed by certain actions and reactions from most other 
members of the group. According to this approach, the "world" of morals would also be directly linked to behavioral facts in a given society, by considering that great part of legal behavior is verbal and consists of rule uttering, a topic that will be explored later on in more detail.

Another central purpose of the present work is to expound a systematic behaviorist approach to law. Some behaviorist ideas have been introduced in legal theory, particularly through the economic analysis of law (cf. Posner, 2007), which emphasizes the relevance of incentives and costs associated to law-related decisions. One of the best examples of behaviorist ideas in law is the chapter by Posner (1990) entitled Ontology, the Mind, and Behaviorism. In this work, the author advances some points that are very akin to behaviorist theories defended by Skinner (e.g., 1953, 1974) and by some ordinary language philosophers (e.g., Austin, 1962; Hacker, 2010; Ryle, 1949; and Wittgenstein, 1953/2009), who have explicated the logic of the usage of psychological concepts and showed that they do not refer to internal, immaterial, events that cause what people do and can only be observed by introspection.

One of the ideas explored by Posner is to question the usefulness of the concept of mind and derived mental concepts in law, such as intention and free will. These concepts have been interpreted in legal theory (and in Psychology, as well) as names of unobservable things that cause people's behavior, when they should rather be interpreted as describing characteristics of behavior and of the contexts in which behavior occurs. In Posner's words: "So while it is true that even a behaviorist (or determinist - I use the terms interchangeably) view of law assumes that the persons whose behavior we want to constrain know what the law requires in the situation in which they find themselves, as well as what that situation is factually (what choices the actor has, and so forth), the ability to comprehend does not require a mind that harbors intentions and directs muscles" (1990, p. 169).

Another point that brings Posner's work close to a behaviorist approach is the emphasis he gives to the effects of environmental consequences in explaining legal behavior, in contrast to explanations that refer to mental entities such as intentions and attitudes, which are common in legal theory. This is a central thesis of economic analysis and utility theory, in which incentives and costs are fundamental elements in the explanation of decisions. From the behavior of criminals (e.g., Becker, 1968) to the behavior of judges (e.g., Epstein, Landes \& Posner, 2011), this type of economic analysis propounds that the consequences following behavior are crucial in determining what people do. When discussing judges freedom to decide cases, for instance, Posner asserts that the decision to obey a rule is compelled not by the rule itself but by the consequences of disobeying it (Posner, 1990, p. 193).

Still another interesting point made by Posner that resembles behaviorist ideas is his assertion that what judges, or academics and lawyers immersed in the judiciary system, say about what they do does not necessarily provide a good description of what they actually do. Considering that most legal theories have been developed by insiders, that is, by intellectuals who operate within the system, this remark gains special relevance. Posner's arguments gravitate around the assumption that people involved in a given situation are not in the best position to describe their behavior, due to motivational factors, such as the possible social consequences resulting from their descriptions, which might influence what they say about what they do. Moreover, judges and legal scholars, who are not necessarily well trained in behavioral observation, have based their descriptions primarily upon introspection, attempting to describe the intellectual and motivational mental operations that accompany their legal activities and decisions. As Posner (1990) wrote: "people systematically misrepresent their motivations to themselves ... The internal perspective on judging may not provide the best explanation for what judges do. A simple behaviorist model may have greater explanative force. Most judges may be quite predictable even though no judge thinks himself predictable" (p. 187).

Therefore, the main novelty of the present proposal does not consist of presenting behavioristinspired ideas in the context of law. This has been done by Posner and others. The novelty here is to present a systematic and more complete behaviorist interpretation of law-related behaviors that might complement existing behavioral perspectives. The 
proposal is systematic because it is based upon theoretical concepts developed in the context of operant theory (e.g., reinforcement, punishment, discriminative stimulus, see Catania, 1998) which have been largely tested in experimental research in the laboratory and in applied settings over the last fifty years or so. The present approach is described as more complete than existing behaviorist-inspired ideas because it includes a behavioral interpretation of language, which is missing in the economic analysis of law and other proposals. According to such interpretation, language consists of verbal behavior (cf. Skinner, 1957) that is influenced by the same types of variables that influence any other behavior, namely, context, motivational operations and consequences. Considering that most legal activities are verbal (e.g., writing petitions and sentences), the incorporation of a theory of verbal behavior complements significantly existing behaviorist approaches to law, among other things, because it makes possible to advance a consistent naturalistic explanation of legal rules (i.e., "law in the books"), as we will attempt to demonstrate further on.

The framework we propose is heavily based on behavior analysis (cf. Skinner, 1953, 1957, 1969) and inspired by sociological system theory (cf. Luhmann, Bednarz \& Baecker, 1995; Luhmann, King \& Albrow, 1985; Teubner, 1993). The proposal rests upon the assumption, advocated by Skinner, that a science of behavior can provide the basis for other social sciences. In this sense, the present approach is in line with the work of other colleagues who, in the last decades, have extended the behavior-analytic framework to interpret and explain social and cultural phenomena, including law (e.g., Todorov, 2005), cultural practices (e.g., Baum, 1995, Glenn, 1988; Mattaini \& Aspholm, 2016), environmental conservation (e.g., Biglan, 2003; Biglan \& Embry, 2013, Geller, 1990; Lehman \& Geller, 2004) and consumer behavior (e.g., Foxall, 1990, 1998, 2016).

For several years now, Aguiar has developed this systematic behavioral interpretation of law, which addresses most of the issues discussed in jurisprudence concerning the characteristics of law (cf. Aguiar, 2012, 2013, 2014, 2015, 2016, 2017; Aguiar \& Gobbo, 2016). In what follows, we will describe the major characteristic of this behavior- analytic approach to law, contrasting it, when appropriate, to more typical interpretations found in jurisprudence and to empirical findings stemming from diverse traditions that study law-related behavior (e.g., criminology, experimental economics) and illustrating its potential to generate areas of research and application.

\section{The Legal System}

Inspired by the concept of functionally specialized social systems, developed by Luhmann (Luhmann, Bednarz, \& Baecker, 1995), Aguiar (2017) proposed that law can be interpreted as a system whose social function is to decrease socially unwanted behavior mostly with the use of coercion. This concept of social system resembles the notion of an interlocking social system mentioned by Skinner, according to which "a controlling agency, together with the individuals who are controlled by it, comprises a social system ..., and our task is to account for the behavior of all participants" (Skinner, 1953, p. 335). In an interlocking social system, the behavior of a given individual produces consequences that influence the behavior of other participants, which in turn may influence back the behavior of the first individual as well as the behavior of other members of the system.

According to Aguiar (2017), functionally specialized social systems have been culturally selected by contingencies that historically affected group practices, in most cases increasing the likelihood of survival and reproduction of the group (cf. Baum, 1995, 2004; Skinner, 1981; Glenn, 1988). The framework proposes that such systems are formed by five components: a macro-problem (recurrent problem related to survival and reproduction of the group), organizations and their products, socially generalized conditioned consequences, problems, and social rules.

In the case of the economic system, for instance, its function is to solve the macro-problem of resource scarcity. The system is composed of organizations such as firms and economic institutions that produce goods to be consumed by members of the social group. Considering that such systems are formed by behavioral patterns that are extended in 
space and time, socially generalized conditioned consequences are needed to maintain such patterns. In the economic system, the generalized conditioned reinforcer is money payment, which reinforces the behavior of producers, employees and bankers (e.g., interest rates). Social specialized systems are also formed by socially relevant problems, which are situations where an individual (or a group) cannot emit a socially adequate response, despite being in the presence of a motivational state (i.e., deprivation or potential punishment) that make that response strong, as Skinner has characterized problem-solving situation, whose solution is a response that alters the situation or the motivational state (1968, p. 132). Macro-problems are too general and abstract to motivate individual behavior; therefore they are translated into more specific problems that affect individuals in their everyday life. Economic proble$m s$, for example, are those that increase or decrease the likelihood of the emission of behaviors related to money payments. So, if the rent is due and there is no money to pay it, there would exist an economic problem, which would increase the likelihood of several responses that in the past generated money or postponed payments. The last component of specialized systems are social rules which are defined as verbal behavior patterns whose occurrence probability depend on their capacity of changing the frequency of certain behavior pattern in the repertoire of a given individual or group of individuals. This definition emphasizes the verbal behavior of the speaker in uttering a rule rather than structural characteristics of certain verbal stimuli (e.g., rules as contingency specifying stimuli) or the behavior that is influenced by rules (e.g., rule-governed behavior), as it has been more frequently emphasized by Skinner and other behavior analysts (for a critical evaluation, see Baum,1995). The definition proposed here is more similar to what Baum (1995) termed rule giving, although in contrast to some observers we do not think it necessary to assume that rule giving is predominantly altruistic, given several historical examples of cultures whose rules benefited only small groups in detriment of the majority (e.g., Acemoglu \& Robinson, 2012). Rules in the economic system would be primarily directed to solve economic problems, which typically involve the maximization of resources through re- ceiving or making money payments. The uttering of rules is functionally related to the maximization of resources of the social group, which would be achieved if all individuals were to behave economically (i.e., as emitting socially adequate responses that increase the probability of receiving payments and decrease the probability of making payments).

\section{Macro-Problem in the Legal System}

In the case of the legal system, or simply law, which is the main focus here, its function is to solve the macro-problem of coercive control of behavior that has been politically defined as socially undesirable. The expression "politically" means collectively binding decisions emanating from the political system, as in the case of a bill approved by Congress (Hart, 1994; Kelsen, 1960/1998; Skinner, 1953). The emphasis on coercive control, which involves the use of situations that have an aversive function to most people in a given society, reflects the predominance of this type of control in law (Albert \& Maluschke, 2013; Kelsen, 1960/1998; Schauer, 2015). Note that in the historical development of legal systems such coercive control has increasingly been reserved for sole exercise by the State, as opposed to allowing individuals to "take the law into their own hands" (Gilissen, 2001; Weber, 1968). This exclusivity in the application of coercive sanctions makes the legal system an essential support for other social systems whose social rules must be enforced. In modern society inadequate behavior may be punished in almost any context, including but not limited to economic, educational, and political. This makes the legal system relevant to almost any social system.

Because the legal system exists primarily to reduce socially unwanted behavior, it consists predominantly of prohibitions, that is, it establishes aversive contingencies with the purpose of controlling socially-defined undesirable behavior. This suggests that the typical behavior that the legal system aims at reducing has been maintained by sources of reinforcement available in their respective contexts. Therefore, the application of legal sanctions must, in order to be effective, overcome existing sources of reinforcement, which calls for a careful functional analysis of the target behavior in designing legal contingencies (e.g., Apel \& Diller, 2017; Nagin, 2013b). 


\section{Legal Organizations and their Products}

The second element of the legal system, according to the present approach, organizations and their products, varies widely across countries. In several countries, there are courts at different levels (such as the Supreme Court, courts of appeal, and district courts in the United States), that have a central coordinative role in the system, plus a general attorney and its offices, different types of police forces, inspection and auditing institutions, public defenders, and private attorney firms. Despite significant differences in their structures and specific functions, all these institutions share the general function of dealing in some way with sanctions to socially undesired behavior, that is, with enforcement.

Theoretically, the level of enforcement, what could be called the force of law, results from interaction of the two behavioral propensities, suggested previously, that exist in all individuals in a society. One is the propensity to offend, that is, to commit crimes, which would be related to the probability, at a given moment, of each individual emitting behaviors that are defined as offenses by law. The analysis of such propensity might be conducted at the general level of a given society in all relevant contexts, or at the level of specific regions or groups in specific contexts (e.g., young adult males in a given city). The other is the propensity to sanction (or to punish), which is related to the probability, at a given moment, of each individual emitting socially adequate behavior that increases the probability of applying sanctions (i.e., events that have aversive function for most people in a given society, such as fines and imprisonment) to those conducts defined as offenses by law. Again, this propensity might be analyzed at different levels, from countries to neighborhoods. The propensity to sanction is said to involve "socially adequate" behavior because, otherwise, these would also constitute offenses. Propensity to sanction would be related to the probabilities associated to several different behavioral patterns, such as calling the police, police patrolling, police investigation, filing lawsuits, judicial sentencing, and so on. The force of law or enforcement would then be a function of the propensities to sanction from the diverse members of the legal system, which encompasses the police, public prosecutors, lawyers and judges, and the propensities to offend of the respective group or population.

\section{Socially Generalized Consequences in the Legal System}

The next element of the legal system is the application of sanctions in the form of socially generalized conditioned consequences. Consequences must fulfill two conditions in order to function as sanctions: They should be distinctly aversive to the vast majority of both potential sanctioners and potential offenders (e.g., similar to punishment intensity, Apel \& Diller, 2017), and they should be contingent upon socially undesired behaviors (e.g., punishment probability and immediacy, Apel \& Diller, 2017). Potential sanctioners are all individuals whose behavior may increase the likelihood of sanctions being applied. Potential offenders are all those who can emit behavior defined by law as an offense.

Legal systems depend on the possibility that sanctions will be applied creating conditioned aversive functions. This may occur when legal sanctions, such as imprisonment, money payments and death are paired with certain verbal patterns associated with them, such as prison, fines and death penalty. Once these verbal patterns have acquired aversive functions, they may be paired with verbal patterns associated with certain behaviors (e.g., killing another person and stealing) and the contexts in which they occur. This may transfer aversive properties to the actual behaviors and discriminative properties to the contexts in which the behaviors occur (i.e., such contexts would indicate an increase in the probability of sanctions being applied). From a behavior-analytic interpretation this would be the main mechanism responsible for possible deterrent effects of law, which explains why increases in the consistency between the emission of verbal patterns and actual application of sanctions increases the deterrent function. For example, Nagin (2013b) described a negative correlation between crime rate and certainty of imprisonment).

\section{Legal Norms}

The last element of the legal system consists of legal norms (including legal rules), a specialized type of social norms. Social norms are socially mediated behavioral patterns (cf. Skinner, 1953, p. 333). 
Such behavioral patterns constitute culturally programmed social contingencies of reinforcement. Specifically, certain types of individual behavior are consistently followed by certain actions and reactions from most other members of the group. These actions and reactions have aversive (or reinforcing) functions. For example, in several countries social norms establish that, in public places or public transportation, healthy people should give their seats to persons with disabilities or elderly individuals. At some locations, there are signs marking reserved seats or indicating that such behavior should occur. The prevailing programmed social contingencies are typically something like the following: If an apparently healthy person is seated during a bus ride and there are no other seats available (or the ones available are too far in the back), and a disabled person gets on the bus, the healthier person should give her seat to the disabled person; otherwise other people or the disabled individual might react with behaviors that are supposedly aversive to the healthier person (e.g., complaining, criticizing, staring). Therefore, punishing consequences are contingent upon the behavior of remaining seated under such circumstances. People learn such norms in a variety of ways: from parents who tell them that they should follow this rule; by observing the behavior of other people and the consequences that follow it; by reading signs describing the requisite behavior; or by repeating behavior that was reinforced in similar circumstances (for a review of research concerning how people learn the law, see Engel, 2008). Social norms are interlocked behavioral patterns in which the consequence for one response might influence the entire chain. If, for example, despite complaints from elderly or disable persons, people stop offering their seats, and other passengers do not support their complains, complaining behavior would tend to stop, and so would the entire chain of social responses.

Legal norms are interlocked behavioral patterns that are maintained and modified by increases or decreases in the probability of the coercive control of politically defined socially undesirable behavior, that is, offenses or crimes. According to this interpretation, such behavioral patterns function as programmed contingencies of social reinforcement that specify that aversive consequences, consisting of actions and reactions of other people, are likely to follow certain responses in certain contexts. For instance, when seeing someone attempting to steal a car, a citizen might call the police, a behavior that initiates an entire chain of responses (e.g., police attending the call, police pursuing and arresting suspects, and so on). Punishing responses can be verbal (e.g., to write a petition addressed to the judge, to make a phone call to the police) or nonverbal (e.g., a police officer might take a suspect to the police station).

Legal norms constitute interlocked behavioral patterns, according to which behavior of group members function as consequences to the behavior of individuals. When one analyzes how such norms influence or come to influence the behavior of group members, it is necessary to focus on the behavior of a given individual, let us say John, for whom the regularities in the behavior of group members function as reinforcement contingencies that alter the probability of John emitting certain behavior. Therefore, if John attempts to steal a car that is parked in a residential area, a neighbor might make a phone call to the police. If the police respond to the call rapidly, a police officer may arrest John at the scene of the crime. Thus, there is a programmed contingency, in this neighborhood, that specifies increased probability of punishment, for example, being taken to the police station and arrested, for behavior of stealing cars or invading properties.

John might learn this contingency by direct contact with such consequences, for instance, by being sent to prison, by seeing other people be sent to prison, or by listening to rules that are uttered by other people (such as parents who say, "One cannot steal. This is wrong and may take you to jail."), which should function as discriminative stimulus (and probably also as a conditioned aversive stimulus), with the function of indicating an increase in the probability of aversive consequences following instances of stealing. A combination of some of these contingencies, rather than a single one, is more likely to apply to most cases. The delinquent behavior might be influenced also by contextual variables. For example, the person might learn by direct experience or by rule transmission that in one neighborhood it is highly probable that people 
will call the police and that the police will respond to the call rapidly, whereas in another neighborhood such consequences are less likely to occur.

In this framework, behavioral patterns are interlocked in the sense that the consequence following one of them is necessary to the occurrence of another behavior in the chain. Calling the police when seeing a car being stolen is reinforced by the arrival of the police, while it also functions as a discriminative stimulus for the police going to the crime scene. Finding evidence of a car being stolen functions as reinforcement for the behavior of police officers responding to the call and may function as a discriminative stimulus for the offender to flee the crime scene. If at a later link of the chain, for instance, when the offender is taken to a court trial, no punishing consequence is imposed by the judge and the offender is freed, all the interlocked behavioral pattern might be weakened. People might become less likely to call the police, the police might be less likely to respond to such calls, and so on. These interlocking behavioral patterns have the function of coercively controlling behavior that has been politically defined as socially undesirable, a function that characterizes legal norms and distinguishes them from other types of social norms. ${ }^{1}$ If the pattern does not produce the consequence of coercively controlling undesirable behavior, it would tend to extinguish.

Legal behaviors and their motivating operations. The interlocked behavioral patterns that form legal norms include what might be called legal behaviors. As any operant behavior, their occurrence can be explained by the combination of four variables: behavioral pattern, motivation, context, and punitive or reinforcing consequences.

Legal behavioral patterns can be functionally classified into punitive and defensive behavior. Punitive behavioral patterns are those that increase

1 Contrast this with the (non-legal) social norm of giving one's seat up on the bus. In most jurisdictions there is no law that requires this behavior, and hence no aversive consequence follows from failing to relinquish the seat. Importantly, without any applicable law, physically coercive behavior is illegal (even for public officials). Thus, any coercive behavior directed towards physically removing the person from the seat would be punishable by public authorities. the likelihood of application of sanction to undesirable behavior, that is, they increase the probability of coercive punishment of offenses. Defensive behavioral patterns, contrarily, are those that decrease the probability of application of sanctions to undesirable behavior, that is, they decrease the probability of punishment of offenses. Both types of patterns vary considerably in topography. Punitive behavior includes instances such as calling the police, writing up a petition by a prosecutor, sentencing by a judge, and such like, whereas defensive behavior can be exemplified by writing a petition by the defending lawyer, presenting a plea of not guilty or accusing another person as being responsible for the crime. Despite this wide variety of topographies, all behavioral patterns, whether punitive or defensive, are functionally similar in the sense that they are influenced by the socially conditioned generalized consequence of law, that is, by changes in the probability of the application of sanctions to socially undesirable behavior.

In the present framework, the motivation is conceived as motivating operation, which is an environmental variable that alters the reinforcing effectiveness of an event and the occurrence probability of behavior that has been reinforced by that event (cf. Laraway, Snyceski, Michael \& Poling, 2003). In the case of punitive legal behavior, the motivating operation is the occurrence or potential occurrence of an offense (i.e., a politically defined socially undesirable behavior), which has aversive function. In the case of a potential offense, its aversive function increases the likelihood of responses that may decrease the probability of its occurrence, such as calling the police or asking a judge for a restraining order. If an offense has actually occurred, the motivation might differ depending upon whether it is a criminal or civil offense. In civil offenses, although the damage caused may motivate punitive behavior, the possibility of receiving financial compensation might function as an additional strong motivating operation. Whereas if a crime is committed, there might be no prospect of receiving money and one might speculate that the motivation may instead be to see the offender suffering ("revenge") and to decrease the probability of repetition of such crimes in the future. As such possible decrease in the probability of crime repetition 
is much delayed in relation to the occurrence of any given crime, behavior is usually influenced by more immediate results, such as the occurrence of events that are associated to increases in the probability of sanctions being applied (e.g., police responding to the call, the scheduling of a court trial).

The motivation for punitive legal behavior emitted by legal authorities derives from the level of aversiveness of the offense added to those associated to organizational contingencies that establish reinforcement and punishment for certain professional responses. Some legal authorities, such as public or private lawyers and tax auditors, might receive money payment associated to successful punitive behavior. Additionally, in most situations, when emitting punitive behavior, legal authorities are applying legal rules, which, ideally, should have important motivational function, including the possibility of punishment of deviant authoritative behavior. In fact, the efficacy of law depends heavily upon the level of control that legal rules (to be discussed later) have on the behavior of legal authorities.

Defensive legal behavior is motivated by the actual or potential occurrence of acts that might increase the probability of a legal sanction being applied to the individual, which in principle have aversive function, such as imprisonment, money payments, loss of properties, compulsory community services, or even death. The aversiveness of punitive acts may be the application of the sanction itself, as when someone has already gone to prison, or it may be an event that has been paired with a sanction, as when someone is summonsed to appear in court. Due to the predominant use of coercive control in law, legal authorities rarely emit defensive legal responses, except for private lawyers and public defendants.

The context in which punitive and defensive legal behavior occur usually involve the actual or virtual presence of a legal authority. This is a consequence of the fact that, in modern societies, legal organizations have the monopoly in the application of coercive sanctions (Kelsen, 1960/1998). This monopoly implies that almost any reinforcement of legal behavior, whether punitive or defensive, depends, ultimately, upon the modification of the propensity to punish of a legal authority (e.g., a judge) in relation to the behavior of a given individual.
The dependency on the behavior of legal authorities raises a peculiar characteristic of legal behavior that it occurs in a social context called, by traditional legal theory, the legal process. In fact, as soon as a legal authority, such as a judge, police officer, prosecutor or lawyer, is called to act upon the application of a legal sanction, the social context changes from that of ordinary life to the context of a legal process. In principle, the planned contingencies imposed by the rules associated to a legal process - that is, the legal procedures - have the function of increasing the probability that the application of sanctions will be influenced by the two most relevant variables from a legal point of view, namely, the emitted conduct and the sanction. In doing this, legal procedures are supposed to decrease the possible influence of irrelevant variables, such as biases related to ideology, race and gender, or other personal characteristics of those involved in a given case. The formality of legal processes, with standardized and strict sequence of steps and deadlines, attempts to minimize the effect of such biases, by treating, ideally, everyone in the same manner.

The consequences that maintain and modify punitive and defensive legal behavior are increases and decreases, respectively, in the probability of the application of sanctions contingently to the behavior of an individual or individuals. This contingency between behavior and sanction constitutes the core of legal rules (Skinner, 1953; Todorov, 2005). As a consequence of the formalities of a legal process, the application (or not) of the sanction occurs after a long chain of legal punitive and defensive responses and, consequently, a long time after the emission of the initial legal behavior. This is why the major consequences for legal behavior is not the application of sanctions but changes in the probability of such application in each link of the behavioral chain. The required intermediate steps of a legal process provide reinforcement and punishment for intermediate responses (i.e., precurrent responses, Skinner, 1969) by producing events that have been correlated to the application of sanctions. These events maintain the emission of intermediate behavior which might, otherwise, not be sufficiently reinforced.

Legal behavioral networks. As mentioned above, punitive and defensive legal behaviors do not occur in isolation. They consist of recurrent behav- 
ioral patterns extended in space and time, which are influenced by previous exposures, directly or indirectly through verbal transmission, to the type of consequence that is likely to follow each pattern. So, as mentioned before, if someone calls the police after witnessing an offense and the police do not go to the location, the likelihood of calling the police on future occasion will probably decrease. By the same token, if a police officer goes to the location and takes the offender to the station but a judge decides to free the person, the probability of attending future calls is likely to reduce.

For this reason, the behavior-analytic interpretation of law proposes the concept of legal behavior network. Legal behavior network refers to the systemic character of legal norms, in which the probability of occurrence of each behavior pattern that constitutes the network depends upon the modifications in the occurrence probability of the other behaviors, which are determined greatly by the reinforcing and punishing consequences experienced, directly or indirectly, by each individual when emitting such behaviors in similar situations in the past. Legal behavior network can be defined as a set of punitive and defensive interlocked legal behaviors existing in a given society at a given moment, where the expression 'interlocked' summarizes the idea that such behaviors influence each other reciprocally and reflexively. The present approach proposes that legal behavior networks are formed by nodes, which consist of points of contact among interrelated behavioral patterns. A node is composed of at least two behavioral patterns, the first one of which functioning as motivation or context for the second (e.g., calling the police creates a context for police coming to the crime scene), and the second one functioning as reinforcement or punishment for the first (e.g., police arrival at the crime scene functions as reinforcement to calling the police). Considering that the social function of law is the coercive control of offenses, the first behavioral pattern of a legal behavior network is usually an offense.

The analysis of legal norms in terms of interlocked legal behavior networks might include three basic phases: 1) mapping the nodes that constitute a given legal behavior network; 2) analyzing the contingencies that prevail in each node, that is, identi- fying the function (e.g., reinforcing, punitive, discriminative, motivating) that each behavior pattern exerts for other behavior patterns; and 3) if it is the case, proposing modifications in the relevant legal rules with the purpose of improving them. Taking as example the case of someone calling the police upon witnessing a person being killed by a gang of delinquents who live in the same neighborhood, it is possible to infer that the probability of someone calling the police will typically depend on this person's previous reinforcing or punishing experiences of calling the police or similar authorities when seeing an offense or something like it. The first node of this sequence would be motivated by the occurrence of the crime and formed by the behavior of calling the police, which functions as discriminative stimulus for the police going to the location, a response that would reinforce the calling behavior. Suppose that the behavior of police officers of responding to calls of this kind is fundamentally reinforced by the cooperative behavior of the witness of going to the police station to testify, identify the criminals and so on, a behavioral sequence that would form a second node. A third node would consist of the behaviors of the witness cooperating with the investigation and the authorities giving protection to the witness in the sense of making sure that her identity remains unknown and, if necessary, giving other types of protection. If the witness is not protected, potential witness would probably not cooperate and, consequently, the offenses will remain unpunished. The analysis of such nodes might suggest crucial points that should be improved in existing contingencies, which can indicate the need of modifying existing legislation, such as the creation or improvement of a program to protect witnesses, in this example.

\section{Empirical Research Related to Legal Norms}

By interpreting law within a naturalistic perspective based on a theory of human behavior, the behavioral analysis of law provides a conceptual framework with strong potential for organizing empirical legal findings and suggesting empirical research and application. The functional analysis of legal systems 
and legal norms encourages the empirical examination of the variables that influence the occurrence of legal behavioral patterns, both in general and in specific legal systems. The approach differs greatly from common practices, found in some countries, based on traditional legal theory which, in contexts where legal decisions must occur, assumes that empirical questions concerning human behavior can be answered without systematic empirical evidence, based on daily unsystematic experiences. In this sense, the present approach is akin to more recent proposals of developing evidence-based legal public policies (e.g., Drake, Aos \& Miller, 2009; Engel, 2016; Henggeler \& Schoenwald, 2011; Nagin, 1998; 2013b).

Most legal empirical studies have been related to legal norms, which can vary in efficiency, that is, can vary in terms of level of enforcement (force of law) relative to their costs. The fundamental task in this line of enquiry has been to identify the variables that are responsible for the level of efficiency of legal norms, which encourages the examination of legal behavior networks and the characteristics of their behavioral nodes. This program would identify the main nodes that compose the behavioral network of a given legal norm, identifying, for each node, context, motivation, behaviors and consequences. By considering that legal networks consist of social contingencies of reinforcement (and punishment), most empirical research related to legal norms investigate parameters of such contingencies, such as the magnitude or probability of the aversive event (i.e., the sanction) or the context and motivational operations involved in a given contingency. Depending upon the type of research question one formulates, this identification can be done at various levels of analysis, ranging from a general analysis of a legal field, such as criminal law or contracts, to a specific analysis of a given law directed to a specific offense, for instance, homicide.

For example, according to the present approach, studies in the criminal field that have compare the deterring effects of punishment severity with those produced by punishment certainty (e.g., Dölling, Entorf, Hermann \& Rupp, 2009; Engel, 2016; Nagin, 2013b) are investigating dimensions of the punishing contingencies across the nodes of the legal behavior network related to criminal offenses. In addition to the severity and certainty of punishment, other dimensions of punishing contingencies that compose legal behavior networks have been considered, such as immediacy of punishment, contemporary reinforcement and strength of competing responses (cf. Apel \& Diller, 2017). This type of research has also analyzed punishing contingencies operating in sequential nodes of the network, as can be illustrated by Nagin's (2013b) assertion that ". . . the certainty of punishment is conceptually and mathematically the product of a series of conditional probabilitiesthe probability of apprehension given commission of a crime, the probability of prosecution given apprehension, the probability of conviction given prosecution, and the probability of sanction given conviction. The evidence in support of certainty's deterrent effect pertains almost exclusively to apprehension probability". Thus, it seems that the concept of legal behavior networks may be useful to organize and integrate findings from the empirical literature by classifying research according to the dimensions of contingencies investigated and the type of node under scrutiny (e.g., apprehension, prosecution, and so on).

Moreover, the proposed interpretation of legal norms encourages the investigation of several phenomena related to interlocked behavioral patterns that constitute legal norms, such as the behavioral propensities (i.e., probability of emitting certain responses) to punish and to offend, associated to different types of socially undesirable behavior. The propensity to punish of legal authorities or institutions has been the focus of considerable volume of empirical research, as can be illustrated by studies that have investigated the probability of sanction application for different crimes (e.g., Hennessy, Rao, Vilhauer, \& Fensterstock, 1999; Nagin, 2013b) and the variables that influence the behavior of judges (e.g., Epstein, Landes \& Posner, 2011, 2013; Oliveira-Castro, Oliveira \& Aguiar, 2018). These lines of research have emphasized specially the propensity to punish of legal institutions, but there is less work on the propensity to punish of people in general or specific groups of people. The propensity to punish found among members of a given society plays a double role in defining the way the legal system works: 1) it influences, with potential votes, the political system, responsible for making 
and changing the text of law, which functions as discriminative stimulus for most legal behavior; and 2) it has a relevant impact on the initiation of legal processes, which frequently depend on ordinary citizens' legal actions, such as filing suits or denouncing offenses. The first step for intensifying the investigation of propensity to punish among group members would involve the development of measures of such punishing propensities, which could be based on combinations of information stemming from, for example, questionnaires, interviews or simulations, that would make possible the assessment of the subjective value of punishing a giving offense (e.g., how much would you pay to have such offense punished?). The propensity to punish should be directly proportional to the levels of occurrence and aversiveness of the offenses, idea that has been corroborated by recent empirical investigation (Melo, 2018).

Research related to the propensity to offend, the counterpart of punish propensity, can be found in studies that attempt to identify, in general, predictors of crimes and offenses, such as those concerned with the possible influences of education, drug use, family conditions and recidivism on the probability of offending (e.g., Ellis, Beaver \& Wright, 2009; Holanda \& Oliveira-Castro, 2019; Southamer-Loeber \& Loeber, 1988), and those investigating the underestimation of punishment probability and risk perception of offenders (e.g., Nagin, 1998, 2013b). According to the present approach, the propensity to offend should be directly proportional to the level of reinforcement produced by the type of behavior and indirectly related to the probability and magnitude of punishment (cf. Apel $\&$ Diller, 2017). The conception of law as a functionally specialized system that coercively controls politically defined undesirable behavior emphasizes the predominance of punitive contingencies in legal systems, an idea that is not necessarily new in legal theory (cf. Schauer, 2015). However, the behavioranalytic view of punishment, according to which there must be alternative sources of reinforcement that maintain the behavior to be punished, stresses the need of examining these existing reinforcement contingencies before defining the type and magnitude of punishment for the target behavior. The effectiveness of punitive contingencies will de- pend upon the level of reinforcement that compete with it. Much empirical research would therefore be necessary for identifying such sources of reinforcement, particularly in the process of elaborating new legislation, that is, in creating legal rules. Results from this type of research, concerned with propensities to punish and to offend, may be useful to calibrate the legal system by altering the punitive contingencies associated to different offenses and to define priority criteria to invest on enforcement. Considering budget restrictions, the enforcement of laws related to the offenses that are, for society, more aversive and occur more frequently might be prioritized.

Considering that legal norms predominantly include punitive contingencies, knowledge concerning the effects of punishment on behavior becomes extremely relevant, which would be an incentive for more basic and applied research, including experimental investigations (cf. Lerman \&Vorndran, 2003). Recently there has been some interesting behavior-analytic research on the effects of punishment using human participants in the laboratory (e.g., Critchfield, Paletz, MacAleese \& Newland, 2003; Pietras, Brandt \& Searcy, 2010). In order to obtain results more closely related to legal behavior, such research procedures might add manipulations of verbal stimuli and verbal behavior, which would lead to the investigation of the effects of punishment on rule following or rule uttering, as illustrated by Fox and Pietras (2013), when examining the effects of punishment on instructional control. The present interpretation of legal norms, as interlocked behavioral patterns, also suggests the experimental investigation of social relations that would include different types of socially delivered punishing consequences. Research on social games (e.g., social dilemma, tragedy of commons) has been extensively adopted to investigate the effects of punishment in the literature on experimental economics (cf. Engel, 2016), and could serve as inspiration for the arrangement of laboratory procedures to study social punishment. In this type of laboratory tasks, participants interact with one another which allows for the examination of social contingencies, particularly when the programmed contingencies predict the possibility of reciprocal punishment (e.g., Balliet, Mulder \& Van Lange, 
2011; Johnson, 2015). If rules are introduced in this type of task, the scenario becomes quite suitable for the examination of responses functionally similar to legal behavior, where the possible effects of variables such as offense aversiveness, probability and magnitude of punishment, reinforcement level for offensive responses, among several others, could be investigated.

\section{Legal Rules}

As mentioned before, in the present work, rule utterances are interpreted as verbal behavioral (Skinner, 1957) patterns whose occurrence probability is influenced by the changes they produce in the frequency of behavioral patterns in the repertoire of an individual or a group. Among the patterns of behavior that constitute legal norms, verbal behavior in the form of rule utterance is very typical and relevant for the maintenance and improvement of such norms. Many punitive and defensive legal behaviors involve rule utterances, such as writing documents by prosecutors and defense lawyers, police orders, judicial sentences, advices given by family members or friends (e.g., "you can be arrested for stealing"), among many others. As rule utterances, such behaviors are influenced by the effects they produce in the behavioral repertoire of listeners or recipients. When the consequence produced by rule utterance is the increase or decrease of behavior of applying sanction to an offense, such behavior is an utterance of a legal rule. Therefore, within the wide set of interlocked behavioral patterns that constitute a legal norm, a large part of such behaviors are verbal responses of uttering legal rules.

The behavior of uttering legal rules, typically, occurs in a context of a legal problem that needs to be solved (cf. Skinner, 1968, 1969, interpretation of problem-solving), having the function of precurrent responses that increase the likelihood of reinforcement for the entire behavior chain. For example, upon being called by a client that has just been arrested, a defensive lawyer is faced with a legal problem, in the sense of being in a situation in which she must emit certain responses that may decrease the probability of her client staying in prison. In this type of context, she is likely to utter several legal rules, probably in the form of a written petition, directed to a judge, of the type "there is no evidence of my client having committed such and such crimes, as specified in such and such laws; moreover, my client does not represent any danger for society, as established by law such and such; therefore my client should be released from prison". As mentioned previously, such defensive legal behavior would be reinforced by changes in the behavior of the judge in the direction of decreasing the probability of her client remaining in prison. Rule uttering has the function of increasing the probability of such reinforcement and has, therefore, precurrent functions (e.g., Polson \& Parsons, 1994; Oliveira-Castro, Coelho \& Oliveira-Castro, 1999). The potential effect that uttering verbal rules, based on specific texts of law that function as discriminative stimuli, has on the behavior of the judge (and, of course, on the reverse direction, from the judge to the lawyer) results from the fact that the law is a political decision that authorizes the use of force to impose modification in the behavior of individuals or groups.

Legal texts exert an important function in the occurrence of legal behavioral patterns, for they provide discriminative stimuli for the utterance of legal rules and the emission of other nonverbal behavior by members of the legal behavior network. For example, a law that establishes for robbery a sanction of 1 to 4 years in prison functions, typically, as a discriminative stimulus to law recipients (i.e., potential offenders, Kelsen, 1960/1998) by indicating an increase in the probability of punishment for such behavior, that is, by indicating the possible existence of certain programmed social contingency. Such text also carries discriminative function for rule uttering by prosecutors and defense lawyers, for the behavior of a police officer arresting a suspect of robbery, for a judge to utter rules in the form of a criminal conviction.

For law recipients, such as the potential offender, the text of the law might function as a discriminative stimulus, which may also have conditioned aversive functions, that indicates increase in the probability of punishment. This discriminative relation may be direct, as when the recipient herself reads the text, or indirectly, as when other people, family members and acquaintances, utter the rule after reading the text or after hearing other people talking about it or after reading other texts related to the same subject. 
In the cases of legal authorities, such as the police officer, the prosecutor and the judge, the discriminative function of this law text might be more complex. In modern societies, the coercive control of behavior is prohibited to everyone, that is, there are legal norms to punish the emission of coercive behaviors in general, with the exception of those cases authorized by law, which specifies who may use coercive means under what circumstances. That is, a law that establishes a prison sentence for robbery exerts discriminative function for some members of the legal behavior network, such as the police officer and the judge, that indicates that the emission of coercive behaviors will not be punished when the sanction is to be applied to a behavior that can be characterized as robbery. Therefore, the text functions, for the judge and the police officer, as a discriminative stimulus for applying sanctions because it indicates a reduction in the probability of punishment of these coercive acts in those specific cases. Almost all the cases in which law texts "authorize" certain public officials to do certain things, the expression has the function of indicating a reduction in the probability of punishment for certain behaviors (Kelsen, 1960/1998, p. 11). This also occurs, for example, in relation to the behavior of spending public resources, for which there are laws authorizing public agents to do so in specific ways and circumstances.

The analysis of the discriminative function of the text of law, in the case of legal authorities, becomes even more complex when one considers that, in addition to being authorized to apply sanctions in certain cases, public authorities have the duty to act coercively in those circumstances indicated by a given law. That is, they are not only authorized, they also must act accordingly. The discriminative function of a criminal law, such as the robbery example cited above, is that the text indicates, to legal authorities, that some punishing consequences for the application of sanction are less likely to occur and that other punishing consequences have been programmed for omission in applying sanctions when they are due.

Therefore, according to the proposed framework, the text is not the rule nor is the rule contained in the text. The presentation of the text of a given law may acquire the function of increasing the probability of rule utterance, which, depending upon the existing contingencies, may influence the repertoire of an individual or group. It should be emphasized, also, that rule utterance is not equivalent to reading the text of a law, or reproducing it orally, although reading or oral reproduction may be part of the behavioral pattern. Reading the text of a given law, or reproducing it orally, may be influenced by several different consequences, such as receiving good grades at a particular exam at law school or finding examples of legal texts with certain characteristics when writing an academic paper. These would be described as instances of reading the text, or stating it, but functionally they would not involve rule utterances related to legal problems. The reason for this is that the main consequence of legal rule utterance, that typically occurs in problem-solving situations, is to change the repertoire of the listener, which, in the case of legal rules, is to change the probability of applying sanctions to acts politically considered to be harmful to the survival, reproduction and well-being of a given society. This modification in the repertoire of the recipient explains the occurrence of rule utterance in its three modes, namely, rule creation, rule transmission and rule application (Aguiar, Oliveira-Castro \& Gobbo, 2019).

In modern societies, the task of creating social rules has been ascribed predominantly to the scientific specialized system. This is a consequence of the fact that social norms, including legal norms, must really work, that is, the behavioral contingencies that constitute a given norm (i.e., interlocked reinforcing and punishing behavioral patterns) must be able to produce the intended state of affairs that is favorable to the survival, reproduction and well-being of society. In other words, in order to be effective, legal rule creation should be based upon a specified causal relation between the coercive control of a given behavior and the attainment of a politically defined socially desirable end. In the absence of such causal relation, punishing the target behavior would not produce the intended results, which would reduce the probability of people applying the rule. In the case of the legal system, the definition of what should be desirable in a given society is established by a binding political decision from the parliament, which we call "law". Such de- 
cisions are usually recorded in standard texts, such as the constitution, the laws and other legal documents in each society.

Rule creation is then a type of rule utterance whose occurrence probability is related to its capacity of modifying the behavior of individuals that transmit and apply that kind of rule in society. In the case of legal rules, the transmitters are law professors and authors of textbooks, whereas the application is typically done by members of legal organizations, mainly lawyers and judges. Legislators, with the help of specialized staff, are usually in charge of creating new rules, although, depending on the type of legal systems, judges and courts can also have a creative role by applying rules in innovative ways.

In order to formulate a behavior-analytic framework to analyze legal rules, Aguiar (e.g., 2017) has proposed to interpret legal rules as composed of the following three elements: relevant factual assumptions, social goal and legal contingencies. Relevant factual assumptions are the basic causal relations between the implementation of the behavioral contingency and the attainment of the desired state of affairs in society. Social goal refers to the desired state of affairs, in the sense of survival, reproduction and well-being of a given society. Finally, legal contingency consists of the coercive contingency between an offense and the application of a sanction. The combination of these three elements provides a behavior-analytic formula to analyze legal rules as scientific rules, in the following manner:

\section{\{GIVEN THAT [the following relevant factual assumptions are valid according to the state of arts in the various sciences], IF [such mediate or immediate consequence of the imposition of the legal contingency mentioned below is a social goal, that is, a politically defined state of affairs favorable to the well-being of the whole group], THEN [the following legal contingency should be implemented by the legal system (IF such conduct, THEN, such sanction)]\}.}

In this formula, relevant factual assumptions refer to the causal relations that, according to what is known in the sciences pertaining to the subject addressed by the legal rule, link the application of the legal contingency and the attainment of the social goal. In fact, in order to be useful to the survival and reproduction of society, the legal system must effectively control, usually by coercive means, socially undesirable behaviors, which must in fact be causally related to the attainment of the desired state of affairs. Factual assumptions that are strongly supported by scientific descriptions of the relations between the implementation of the contingency and the attainment of the specified goal tend to increase the effectiveness of a legal rule. For example, the criminalization of the recreational use of marijuana with the purpose of decreasing long-term health problems in the population must demonstrate, firstly, that punishing recreational use will decrease the consumption of marijuana, and, secondly, that there is a causal relation between the consumption of marijuana and the incidence of certain diseases according to medical science. Therefore, if any of these assumptions is falsified (i.e., verbal responses stating them are not socially reinforced or are punished), one can conclude that the institution of the new legal contingency will not be effective for the attainment of the politically defined social goal.

Each legal rule will involve different and diverse assumptions, concerning information from different areas of knowledge, but, in general, a behavioral analysis of legal rule should examine, at least, four categories of assumptions: 1) the occurrence probability of the behavior to be coercively controlled; 2) the potential effectiveness of the sanction; 3) possible undesirable effects stemming from the application of the sanction; and 4) causal nexus between the sanctioned conduct and the social goal. The first three categories of assumptions are mainly concerned with the attainment of the immediate goal of decreasing undesirable behavior. The fourth category focuses on the attainment of the mediate goal, that is, the final social goal of the specified legal rule, which may or may not coincide with the immediate goal. In the case of decreasing homicide, the immediate goal of decreasing such behavior is the ultimate goal. In the case of criminalizing the recreational use of marijuana, as cited above, the ultimate goal is to increase, in the long term, the health of the population, which differs from the immediate goal of decreasing marijuana consumption. 
Social goal is the state of affairs politically defined as socially desirable, the attainment of which, according to the relevant factual assumptions, depends directly or indirectly upon the institution of the legal contingency. As mentioned previously, social goal can be immediate or mediated. Immediate social goal is always the decrease of undesirable behavior. Mediated goals presumably result from the decrease of undesirable behavior. Sometimes immediate and mediated goals coincide, as in the case of homicide, mentioned above. The social goal of a given law is not usually recorded in its text. Its record can be found frequently in the texts that were generated during the discussion of the draft bill, such as in the justifications for proposing the new bill.

Legal contingency is the contingent relation specified by the legal rule between the offense and the sanction, that is, between the socially undesirable conduct and the presumed aversive consequence. The contingent relation is said to be specified by the rule in the sense that rule utterance functions as discriminative stimulus for the behavior of members of the legal behavior network, who might punish (or defend) the act, and the behavior of potential offenders, whose behavior might be punished (or defended). From a behavior-analytic point of view, the main function of legal rules is to specify reinforcement contingencies (Skinner, 1953), whose specification may be more or less completely recorded in the text of law (Todorov, 2005).

It is relevant to notice that some potentially aversive consequences associated to legal behavior, such as visiting a police station as a witness or a victim, may decrease the likelihood, for example, of someone reporting a crime, but do not constitute legal contingencies, according to the above definition. They do not involve a contingency between an offense and a sanction. These behavioral patterns do belong to the interlocked contingencies that constitute legal norms and, as such, might need to be examined by researchers; however, they are not part of legal contingencies.

\section{Empirical Research Related to Legal Rules}

Whereas the theoretical interpretation of legal norms, as proposed here, might be useful in organizing existing empirical results and suggesting more emphasis in some of the investigated variables (e.g., consequences for different responses), the theoretical interpretation of legal rules provides a completely new framework to analyze legal behavior and legal texts. The main point of novelty in the present approach is the adoption of a functional interpretation of verbal behavior, which is lacking in other treatments of legal behavior. A prevalent type of behavior that compose interlocked behavioral patterns that constitute legal norms is the utterance of rules, as mentioned previously. These utterances, that usually occur in the presence of legal texts that function as discriminative stimuli, are influenced mostly by the consequences they produce which are correlated with increases (in the case of punishing legal behaviors) or decreases (in the case of defensive legal behaviors) in the probability of application of sanctions. The proposed framework to analyze legal rules, as verbal responses of uttering rules in the context of solving legal problems, highlights the function of the three elements that compose legal rules, namely, relevant factual assumptions, social goal and legal contingency.

These elements can be interpreted as features that are present in the context of solving legal problems and that influence the behavior of those involved, by functioning as discriminative stimuli for their responses. When a judge decides if she should apply a sanction to a given individual, her decision will depend upon, among other things, the evidence that support factual assumptions related to the respective rule. The evidence should at least demonstrate that, in situations such as the one being evaluated, the application of this type of sanction has been vastly demonstrated to reduce the occurrence of the undesirable behavior and that decreases in such behavior increases the likelihood of achieving the desired end. Additionally, there must be enough evidence showing that the person did in fact commit the offense. For example, if a judge has to decide whether or not she should apply a sanction to a teenager for using marijuana, the probability of applying the sanction will tend to increase with increases in the amount of evidence showing that: 1) this type of sanction tends to decrease the use of marijuana (immediate goal); 2) marijuana usage causes serious health problems (mediate goal); 3 ) the teenager did in fact use mari- 
juana (necessary part of the contingency). This analytic framework sets the ground to several new lines of research and application. One of them would be related to the identification and examination of such elements (i.e., relevant factual assumptions, social goal and legal contingency) associated to legal texts with the purpose of analyzing their potential discriminative functions for the behavior of different individuals or institutions that take part in legal disputes, such as judges, defendants, plaintiffs, police officers and public agents. A methodology to analyze legal rules, based upon this framework, has been recently developed and applied to laws created to control fiscally irresponsible behavior (cf. Aguiar \& Oliveira-Castro, no prelo; Oliveira, 2016).

Another promising line of enquiry would be the analysis of rule uttering by different stakeholders in legal disputes, by identifying the types of elements of legal rules that appear in their verbal behavior and measuring their probability of occurrence. For instance, according to the present framework, the propensity to punish by a legal authority plays a crucial function in legal networks, in the sense that it influences, more or less directly, the behavior of most individuals acting in a given network. As mentioned previously, the behavior of the judge functions, in the large majority of legal cases, as the final consequence of a long chain of legal behavior emitted by parties, attorneys, and such like. Therefore, legal responses that change the likelihood of the application of sanction by the judge should be highly probable. The proposed analytic framework, developed to analyze legal rules, provides tools for the functional identification of this type of legal responses, which should be related to the elements of a legal rule. This is so because these elements function as discriminative stimuli for the behavior of the legal authority, in the sense that the probability of reinforcement (or absence of punishment) for the authority's decision will change depending upon the presence of such elements (e.g., amount of evidence supporting the causal relation between application of sanction and decrease in unwanted behavior or that the person committed the offense). From this, it is expected that many legal verbal responses by attorneys, for instance, will be associated to the elements of the legal rule formula. In the case of prosecutors, the present approach predicts that a great portion of their verbal responses that appear in their written documents will consist in attempts to reassure that there is enough evidence to support the basic elements of the legal rule (e.g., that the behavior being discussed should be classified as such and such crime or that the accused did commit the crime), since this might function as discriminative stimuli that increase the probability of the authority applying a given sanction. Defendants' verbal behavior, on the other hand, would tend to deny that there is enough evidence to support the assumptions, which might decrease the probability of sanction application. These types of predictions suggest various areas of empirical research concerning rule uttering from legal parties. One promising line of investigation would involve the examination of the frequency of these different types of verbal responses (i.e., related to conceptual or empirical aspects of the assumptions) that are emitted by different stakeholders (e.g., plaintiffs, defendants, judges) or occur in different legal fields (e.g., criminal, tax or liability cases) or in different countries. It might be useful, for example, to identify legal networks (e.g., different fields of law or countries) in which there might be a predominance of rule uttering associated to conceptual discussions of the assumptions (e.g., "this type of sexual relation during a date cannot be characterized as sexual assault"), which are usually referred to as "questions of interpretation", and to compare them to other networks where there might be more empirical discussions of the assumptions (e.g., "there is no evidence that the accused did coerce the defendant").

\section{Conclusion}

The present work presented a naturalistic theory of law and legal systems firmly grounded in a science of behavior, particularly in operant theory. According to this approach, law can be understood as a social system that is functionally specialized in the coercive control of behaviors that are politically considered to be harmful to the survival, reproduction and well-being of society. Such control is exerted through legal norms which are conceived as interlocked behavioral patterns that are maintained and modified by increases or decreases in the prob- 
ability of the application of sanctions contingent to politically defined socially undesirable behavior. Most empirical research developed in law is related to the examination of aspects of legal norms, which can be described as studies that investigate the parameters of contingencies in effect in legal systems, usually aiming at improving the efficiency in the control of socially unwanted behavior.

The approach proposes a distinction between legal norms and legal rules, with the purpose of providing a naturalistic interpretation of the distinction, frequently found in jurisprudence, between law in action and law in the books. Legal rules would form a subset of legal norms, consisting of verbal behavioral patterns of uttering rules, which are influenced by the consequences they produce in increasing or decreasing the probability of a sanction being applied to a given behavior. This concept of legal rule encourages a functional investigation of the verbal behavior emitted by the main agents of the legal system, such as lawyers, prosecutors and judges, in the context of solving legal problems.

One of the main reasons for advancing the present proposal is the ascertainment that although legal systems have the function of controlling behavior in society they have been developed and implemented without the support of a systematic theory of behavior. We believe that the behavioranalytic framework, including operant theory and classical conditioning, constitutes a good candidate to provide the basis for such systems, considering its long and consistent history of experimental research and conceptual development, which makes it a rare case of sound theoretical enterprise in the social and behavioral sciences.

\section{References}

Abbink, K., Dasgupta, U., Gangadharan, L., \& Jain, T. (2014). Letting the briber go free: An experiment on mitigating harassment bribes. Journal of Public Economics, 111, 17-28. https://doi. org/10.1016/j.jpubeco.2013.12.012

Acemoglu, D., \& Robinson, J. A. (2012). Why nations fail: the origins of power, prosperity, and poverty. New York: Crown Business.
Aguiar, J. C. (2012). Legal contingencies: towards a radical behaviorist approach to law as a social system, Doctoral thesis, University of Aberdeen, Scotland, United Kingdom.

Aguiar, J. C. (2013). O direito como sistema de contingências sociais. Revista da Faculdade de Direito da Universidade Federal de Goiás, 37(2), 164-196. https://doi.org/10.5216/rfd. v37i2.23681

Aguiar, J. C. (2014). Análise comportamental do direito: uma abordagem do direito como ciência do comportamento humano aplicada. Nomos, 34(2), 245-273.

Aguiar, J. C. (2015). Passos para uma abordagem evolucionária do direito. Revista da Faculdade de Direito da Universidade Federal do Paraná, 60(1), 9-38. http://dx.doi.org/10.5380/rfdufpr. v60i1.36244

Aguiar, J. C. (2016). Análise comportamental do direito: ideias básicas. In: B. M. Tabak, \& J. C. Aguiar, Direito, Economia e Comportamento Humano (pp. 15-26). Curitiba: CRV.

Aguiar, J. C. (2017). Teoria analítico-comportamental do direito. Porto Alegre: Núria Fabris.

Aguiar, J. C., \& Gobbo, L. O. (2016). Behavior analysis of law: a brief overview of the juxtaposition of law and radical behaviorism. In: J. C. Todorov, Trends in behavior analysis (pp. 81103). Brasília: Technopolitik.

Aguiar, J. C., \& Oliveira-Castro, J. M. (no prelo). Direito, política e economia na LRF: uma análise comportamental da Lei Complementar $n^{\circ} 101$, de 4 de maio de 2000.

Aguiar, J. C., Oliveira-Castro, J. M., \& Gobbo, L. O. (2019). Rules as basic units of sociocultural selection. Perspectives on Behavior Science, 42, 851-868. https://doi.org/10.1007/s40614-01900201-6

Albert, H., \& Maluschke, G. (2013). O direito à luz do racionalismo crítico, Brasilia: Universa/UnB.

Apel, A. B., \& Diller, J. W. (2017). Prison as punishment: A behavior-analytic

evaluation of incarceration. The Behavior Analyst, 40(1), 243-256. https://doi.org/10.1007/s40614016-0081-6

Austin, J. L. (1962). How To Do Things With Words. Oxford: Clarendon Press.

Balliet, D., Mulder, L. B., \& Van Lange, P. A. M. 
(2011). Reward, Punishment, and Cooperation: A Meta-Analysis. Psychological Bulletin, 137(4), 594-615. https://doi.org/10.1037/a0023489

Baum, W. M. (1995). Rules, culture, and fitness. The Behavior Analyst, 18(1), 1-21. https://doi. org/10.1007/BF03392688

Baum, W. M. (2004). Understanding Behaviorism: Behavior, Culture, and Evolution (2nd Ed.). Oxford: Blackwell Publishers.

Becker, G. S. (1968). Journal of Political Economy,76(2), 169-217. https://doi.org/ doi:10.1086/259394

Biglan, A. (2003). Selection by consequences: One unifying principle for a transdisciplinary science of prevention. Prevention Science, 4(4), 213 232. https://doi.org/10.1023/A:1026064014562

Biglan, A., \& Embry, D. D. (2013). A framework for intentional cultural change. Journal of Contextual Behavioral Science, 2, 95-104. https://doi.org/10.1016/j.jcbs.2013.06.001

Catania, A. C. (1998). Learning (4th ed.). Upper Saddle River, NJ: Prentice Hall.

Critchfield, T. S., Paletz, E. M., Macaleese, K. R., \& Newland, M. C. (2003). Punishment in human choice: Direct or competitive suppression? Journal of the Experimental Analysis of Behavior, 80(10), 1-27. https://doi.org/10.1901/ jeab.2003.80-

Dölling, D., Entorf, H., Hermann, D., \& Rupp, T. (2009). Is deterrence effective? Results of a meta-analysis of punishment. European Journal on Criminal Policy \& Research, 15(1/2), 201-224. https://doi.org/10.1007/s10610-008-9097-0.

Drake, E. K., Aos, S., \& Miller, M. G. (2009). Evidence-based policy options to reduce crime and criminal justice costs: implications in Washington state. Victims and Offenders, 4, 170-196. https://doi.org/10.1080/15564880802 612615.6im-.

Ellis, L., Beaver, K., \& Wright, J. (2009). Handbook of crime correlates. Cambidge, MA: Academic Press.

Engel, C. (2008). Learning the Law. Journal of Institutional Economics, 4, 275-297. https://doi. org/10.1017/S1744137408001094

Engel, C. (2016). Experimental criminal law: A survey of contributions from law, economics and criminology. Preprints of the Max Planck
Institute for Research on Collective Goods Bonn 2016/7, SSRN Eletronic Journal. https:// doi.org/10.2139/ssrn.2769771

Epstein, L., Landes, W. M., \& Posner, R. A. (2011). Why (and when) judges dissent: A theoretical and empirical analysis. Journal of Legal Analysis, 3(1), 101-137. https://doi.org/10.1093/ jla/3.1.101

Epstein, L., Landes, W. M., \& Posner, R. A. (2013). The Behavior of Federal Judges: A Theoretical \& Empirical Study of Rational Choice. Cambridge, MA: Harvard University Press.

Fox, A. E., \& Pietras, C. J. (2013). The effects of response-cost punishment on instructional control during a choice task. Journal of the Experimental Analysis of Behavior, 99(3), 346361. https://doi.org/10.1002/jeab.20

Foxall, G. R. (1990). Consumer psychology in behavioral perspective. New York: Routledge.

Foxall, G. R. (1998). Radical behaviorist interpretation: Generating and evaluating an account of consumer behavior. The Behavior Analyst, 21(2), 321-354. https://10.1007/BF03391971

Foxall, G. R. (Ed.) (2016). The Routledge Companion to Consumer Behavior Analysis. New York: Routledge.

Geller, E. S. (1990). Behavior analysis and environmental protection: Where have all theflowers gone? Journal of Applied Behavior Analysis, 23, 269-273. https://doi.org/10.5210/bsi.v13i1.33

Gilissen, J. ( 2001). Introdução histórica ao direito (A. M. Hespanha and M. M. Malheiros, Trans.). Lisbon: Calouste Gulbenkian.

Glenn, S. S. (1988). Contingencies and metacontingencies: Toward a synthesis of behavior analysis and cultural materialism. The Behavior Analyst, 11(2), 161-179. https://doi.org/10.1007/ BF03392470

Habermas, J. (1996). Between Facts and Norms: Contributions to a Discourse Theory of Law and Democracy (W. Rehg, Trans.). Cambridge, MA: MIT Press.

Hacker, P. M. S. (2010). Human Nature: the categorial framework. Wiley-Blackwell.

Hart, H. L. (1994). The Concept of Law. Oxford: Claredon.

Henggeler, S. W., \& Schoenwald, S. K. (2011). Evidence-based interventions for juve- 
nile offenders and juvenile justice policies that support them. Sharing Child and Youth Development Knowledge, 25(1), 1-20. https:// doi.org/10.1002/j.2379-3988.2011.tb00066.x

Hennessy, J. J., Rao, V. P., Vilhauer, J. S., \& Fensterstock, J. N. (1999). Crime and punishment: infrequently imposed sanctions may reinforce criminal behavior. Journal of Offender Rehabilitation, 29(1/2), 65-75. https://doi. org/10.1300/J076v29n01_05

Holanda, A. O., \& Oliveira-Castro, J. M. (2019). Behavioral-economic analysis of delinquent acts based on the report of juvenile offenders in confinement. Psicologia: Teoria e Pesquisa, 35, e35514. https://doi. org/10.1590/0102.3772e35514

Johnson, S. (2015). Escaping the tragedy of the commons through targeted punishment. Royal Society Open Science, 2, 150223. https://dx.doi. org/10.1098/rsos.150223

Kelsen, H. (1998). Teoria Pura do Direito (J. B. Machado, Trans.). São Paulo: Martins Fontes. (Original work, Reine Rechtslehre, published in 1960).

Laraway, S., Snycerski, S., Michael, J. \& Poling, A. (2003). Motivating operations and terms to describe them: some further refinements. Journal of Applied Behavior Analysis, 36(3), 407-414. https://dx.doi.org/10.1901/jaba.2003.36-407

Lehman, P. K., \& Geller, E. S. (2004). Behavior analysis and environmental protection: Accomplishments and potential for more. Behavior and Social Issues, 13(1), 13-32. https:// doi.org/10.5210/bsi.v13i1.33

Lerman, D. C., \& Vorndran, C. M. (2002). On the status of knowledge for using punishment: Implications for treating behavior disorders. Journal of Applied Behavior Analysis, 35(4), 431464. https://doi.org/10.1901/jaba.2002.35-431

Luhmann, N., King, E., \& Albrow, M. (1985). A sociological theory of law. London: Routledge \& Kegan Paul.

Luhmann, N., Bednarz, J. J., \& Baecker, D. (1995). Social systems. Stanford, CA: Stanford University Press.

Mattaini, M. A., \& Aspholm, R. (2016). Contributions of behavioral systems science to leadership for a new progressive movement.
The Behavior Analyst, 39(1), 109-121. https:// doi.org/10.1007/s40614-015-0043-4

Melo, R. R. (2018). Propensões a punir atos delitivos: um modelo para análise de contingências do sistema jurídico. Dissertação de mestrado, Universidade de Brasília, Brasília, DF.

Nagin, D. S. (1998). Criminal deterrence research at the outset of the twenty-first century. Crime and Justice, 23, 1-42. https://doi.org/10.1086/449268 Nagin, D. S. (2013a). Deterrence: A Review of the Evidence by a Criminologist for Economists. Annual Review of Economics, 5, 83-105. https://doi.org/10.1146/annurev-economics-072412-131310

Nagin, D. S. (2013b). Deterrence in the twenty-first century. Crime \& Justice, 42(1), 199-263.

Oliveira, A. (2016). Comportamento de gestores de recursos públicos: identificação de contingências previstas e vigentes relativas à prestação de contas. Tese de doutorado, Universidade de Brasília, Brasília, DF.

Oliveira-Castro, J. M., Coelho, D. S., \& OliveiraCastro, G. A. (1999). Decrease of precurrent behavior as training increases: Effects of task complexity. The Psychological Record, 49, 299325. https://doi.org/10.1007/BF03395322

Oliveira-Castro, J. M., Oliveira, A., \& Aguiar, J. C. (2018). Análise comportamental do direito: aplicação de sanções pelo Tribunal de Contas da União a gestores com contas irregulares. Revista de Estudos Empíricos em Direito, 5(2), 146-161. https://doi.org/10.19092/reed.v5i2.245

Pietras, C. J., Brandt, A. E., \& Searcy, G. D. (2010). Human responding on random-interval schedules of response-cost punishment: The role of reduced reinforcement density. Journal of the Experimental Analysis of Behavior, 93(1), 5-26. https://doi.org/10.1901/jeab.2010.93-5

Polson, D. A., \& Parsons, J. A. (1994). Precurrent contingencies: Behavior reinforced by altering reinforcement probability for other behavior. Journal of the Experimental Analysis of Behavior, 61,427-439. https://doi.org/10.1901/ jeab.1994.61-427

Posner, R. A. (1990). The Problems of Jurisprudence. Cambridge, MA: Harvard University Press.

Posner, R. A. (2007). Economic Analysis of Law (7th ed.). New York: Aspen Publishers. . 
Ready, J. T., \& Young, J. T. N. (2015). The impact of on-officer video cameras on police-citizen contacts: Findings from a controlled experiment in Mesa, AZ. Journal of Experimental Criminology, 11(3), 445-458. https://doi.org/10.1007/s11292015-9237-8

Ryle, G. (1949). The Concept of Mind. London: Hutchinson.

Schauer, F. (2015). The Force of Law. Cambridge, MA: Harvard University Press.

Skinner, B. F. (1953). Science and human behavior. New York: Free Press.

Skinner, B. F. (1957). Verbal behavior. Englewood Cliffs, NJ: Prentice-Hall.

Skinner, B. F. (1968). The technology of teaching. New York: Appleton-Century-Crofts.

Skinner, B. F. (1969). Contingencies of reinforcement: a theoretical analysis. New York: AppletonCentury-Crofts.

Skinner, B. F. (1974). About Behaviorism. London: Jonathan Cape.

Skinner, B. F. (1981). Selection by consequences. Science, New Series, 21 (4507), 501-504.

Southamer-Loeber, M., \& Loeber, R. (1988). The use of prediction data in

understanding delinquency. Behavioural Sciences \& the Law 6(3), 333-354. https://doi.org/10.1002/ bsl.2370060305

Teubner, G. (1993). Law as an autopoietic system. Oxford: Blackwell.

Todorov, J. C. (2005). Laws and the complex control of behavior. Behavior and social issues, 14, 8691. https://doi.org/10.5210/bsi.v14i2.360

Weber, M. (1968). Economy and Society: an outline of interpretive sociology (Guenther Roth and Claus Wittich, Eds.). New York: Bedminster Press.

Wittgenstein, L. (1953/2009). Philosophical investigations. (Translated by G.E.M. Anscombe, P.M.S. Hacker, and Joachim Schulte - Rev. 4th ed. / by P.M.S. Hacker and Joachim Schulte). Wiley-Blackwell.

\section{Informações do Artigo}

Histórico do artigo:

Submetido em: 16/08/2019

Primeira decisão editorial: 20/08/2020

Aceito em: 31/08/2020

Editora associada: Natália Santos Marques 